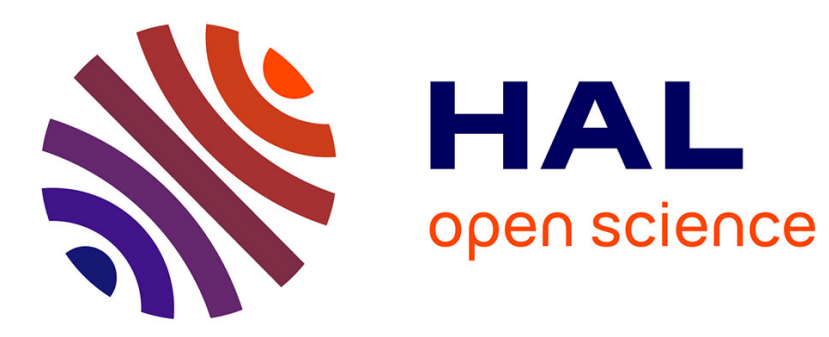

\title{
What Is Documentation?
}

Yves-François Le Coadic

\section{To cite this version:}

Yves-François Le Coadic. What Is Documentation?. 2007, 10.1086/521003 . sic_00203384

\section{HAL Id: sic_00203384 \\ https://archivesic.ccsd.cnrs.fr/sic_00203384}

Submitted on 9 Jan 2008

HAL is a multi-disciplinary open access archive for the deposit and dissemination of scientific research documents, whether they are published or not. The documents may come from teaching and research institutions in France or abroad, or from public or private research centers.
L'archive ouverte pluridisciplinaire HAL, est destinée au dépôt et à la diffusion de documents scientifiques de niveau recherche, publiés ou non, émanant des établissements d'enseignement et de recherche français ou étrangers, des laboratoires publics ou privés. 
“Documentation is dead; long live documentation!" Forty years ago, American professionals wanted to highlight their contribution to building the infrastructure of a new science and a new industry, namely, information science and the information industry. They changed the name of their profession. Less concerned with documents, they no longer wanted to be called documentalists. So why now republish a book entitled What Is Documentation? Is the book anachronistic, a piece of historical research, or an effort to use the past to put new questions on the agenda of current research? Well, it certainly is not an anachronism.

In publishing this book Ronald E. Day, Laurent Martinet, and Hermina G. B Anghelescu's goal is first and foremost to build a better historical understanding of professional information practices. They have translated and critically analyzed a text originally published in 1951 by the French documentalist Suzanne Briet entitled Qu'est-ce que la documentation? Their book contains Day's introduction; a very high-quality English translation of Briet's text; a biographical note; and selected bibliography of Briet's writings compiled by Michael Buckland, who was the American discoverer of this French pioneer; and, finally, an article by Day entitled "“A Necessity of Our Time”: Documentation as a 'Cultural Technique' in What Is Documentation?" This article directly addresses questions currently under discussion by both the profession and academics.

Day sets the scene in his introduction by insisting on what he calls the cultural dimension of documentation. Documentation techniques were constructed in reaction to the more technical but highly restrictive and limited goal of library and archival science, which was to manage books and documents. For Briet, managing books and documents required more than just technical skills; it meant understanding social structures and user needs as well. If documentalists wanted to get information out to a wide audience, they would have to become better versed in the social sciences. Briet was very much influenced by the technical universalism of her day, which held that people would inevitably learn how to master the techniques at their disposal. She stressed the human element, the need to understand the user. Even today the impact of her message continues to be felt at the Institut National des Techniques de la Documentation (INTD) she created fifty years ago, an institute that remains in some aspects (recruitment, courses, full-time teachers) an institute of the 1950s. The cultural dimension of documentation remains the strong point of this institute, which recruits students who have a social science background. However, the technical universalism of Briet's epoch is gone. Another message is being heard today: documentalists should be better trained in information science and technology. 
In his biography, Buckland considers that Briet's text is a manifesto (i.e., a public declaration of principles and intentions, often political in nature) that can be parodied using Karl Marx: "Workers of documentation unite; you have nothing to lose but your library chains!” For Briet, the revolution underway was that of information's industrialization. It would have widespread impact on not only society but also sciences such as semiotics and linguistics. But her text is much too enthusiastic and largely ignores the scientific and technical realities of the information world. Information science has gone a long way in describing those realities: today, information scientists work with computer scientists, use mathematical models for understanding document flows, develop social theories and linguistic techniques for accessing content, and use infometric methods for improving document search strategies. Their field of activity is situated somewhere along a continuum running from social economics on one side to the physical theory of information on the other side. Finally, the influence of technical universalism led Briet to largely ignore the need to consider documentation as an empirical science. This is no longer the case with today's information science. The development of experimental platforms for verifying, refuting, and collectively constructing hypotheses is now normal practice in the field.

Both Day and Buckland consider documentation as a typically European phenomenon, more specifically French and Belgo-French in origin, even though there were exchanges with the British and German professional communities. And with respect to Briet's text, they consider it as being the expression of an enlightened professionalism, but a professionalism that is detached from science. Documentation became a technique without scientific sensitivity, without a link with any science, in particular with what was going to become information science. By taking information as its object of study, information science broke with a tradition that had been forged in opposition to library and archival science, but which nevertheless reproduced their limitations. Documentation remained focused on documents but gained a cultural dimension. If the Anglo-Saxon information culture knew how to assimilate the paradigmatic shift of information science (with the passage of the American Documentation Institute to the American Society for Information Science and Technology), the French information culture is still experiencing today a great deal of difficulty doing so. For proof, France's two professional schools are still separated, with the INTD focused on documentation centers and the other, the Ecole Nationale Supe rieure des Sciences de l'Information et des Bibliothe'ques (ENSSIB), on libraries. There is very little information science practiced at INTD and ENSSIB and very little information science practiced generally in universities throughout France. 
Readers might conclude from what has been said thus far that the text by Briet is out of touch with the world of information science today, that it initiated a move toward introducing a cultural dimension into the field, but, now, that the pendulum has swung back to a harder, more science-oriented position. But this is not the case, as Day shows in his closing article to the book. He uses Briet's text to put several questions on the table. The first touches on the French situation described above. Briet initiated a paradigm change, according to Day. She subordinated the use of technical skills in favor of a better understanding of the cultural and social contexts in which these skills are used. She refused to look upon the conceptual and methodological practices of documentation as providing tools for managing books and documents. They were, to her mind, techniques to help get information to people, and because of that you have to know what people need. That said, she misread the need for technical proficiency because she was convinced that people would know how to use documentation techniques to get the information they needed, if only they were helped to formulate those needs in the first place. In other words, the paradigm shift is similar to opening the door and crossing the road. Instead of seeing things from a technical point of view-librarians and archivists were too bogged down in technical considerations - she suggested looking at things from the opposite direction. She viewed things through the lens of cultural studies but did not attempt to close the gap separating technical skills, on the one side, and social skills, on the other side. To the contrary, all she did was to cross the road. And that is where France is today. Documentation is a field strongly anchored in the social sciences. Information is a field strongly anchored in the engineering sciences. The two fields are interacting with one another, but from across the road, separated by a great divide.

A great deal of work is currently under way to break down the great divide separating the social and the technical, and this is the second and truly interesting point in Day's analysis. Briet assumed that the cultural dimension of documentation would take on particular importance with the extension of technical networks. For Day, her analysis of this idea announces in a premonitory way how various traditions of research are now working at exploiting the traces of electronic documents to knot a seamless web between the technical and the social. Actor Network theorists, people working on computer-supported cooperative work, and people attempting to understand distributed collective practices are all building experimental procedures for formulating and testing hypotheses that show the power of sociodiscursive networks in breaking down the great divide. But documentalists, in France at least, are far from being "ahead of the scientist" in this work on bridging the gap (p. 56). They exist "through cultural productions not before them" (p. 61). The profession remains a service 
profession: more servant than prospector (more "milkmaid" than "dog on the hunt" [p. 51]). And it does not seem able with the present cursus to manage interdisciplinary collaborations between these various cultures.

We can conclude from this discussion that Briet's work is both an obstacle and an incentive to putting new questions on the information profession's agenda. It is an obstacle, because one reading of her work sees technical skills pitted against social skills. To my mind, this is where France is at the present time. France's university system is still locked into a cultural quarrel where documentalists defending humanist, social science values are fighting against engineers who see information science as needing more mathematics, models, and experimentation. But Briet's work is also an incentive to break down the walls of this misunderstanding. When her book is read from the point of view of building sociodiscursive networks, it becomes an instrument for working together over the great divide. At least that is what Day seems to be saying when he explains how different research traditions are using documentation to generate hypotheses of interest to information science research. We would like to give special thanks to our American colleagues for their interest in French and European documentation history. In the past, it has been hard to get French historians (in particular) to study the subject. It still is, but maybe this book will kindle their interest. 